Paula TOMASZEWSKA

Uniwersytet im. Adama Mickiewicza w Poznaniu ${ }^{1}$

Wydzial Nauk Politycznych i Dziennikarstwa

Zaklad Studiów Strategicznych

paula.tomaszewska@amu.edu.pl

ORCID 0000-0003-0583-0938

https://doi.org/10.34739/dsd.2019.02.09

\title{
CHIŃSKA INICJATYWA PASA I SZLAKU \\ A RYZYKO ZADLUŻENIA JEJ BENEFICJENTÓW
}

\begin{abstract}
ABSTRAKT: Chińska inicjatywa Pasa i Szlaku (Belt and Road Initiative - BRI) jest nie tylko projektem gospodarczym czy politycznym, lecz także mającym potencjał do transformacji systemu międzynarodowego. Wpływ inicjatywy jest duży - od stymulowania finansowania inwestycji infrastrukturalnych w różnych państwach na świecie, po rozwój nowych globalnych łańcuchów dostaw. Celem naukowym artykułu jest analiza konsekwencji wdrażania inicjatywy Pasa i Szlaku. Problem badawczy sprowadza się do pytania: czy ta inicjatywa przyczynia się do zwiększenia chińskich wpływów na świecie i niesie za sobą ryzyko wpędzania biedniejszych państw w ,pułapkę zadłużenia" poprzez projekty realizowane w nietransparentny sposób? Wnioskiem płynącym z artykułu jest stwierdzenie, że Chiny powinny stworzyć ulepszoną wersję inicjatywy BRI opartą o lepszą ocenę ryzyka realizowanych projektów. Jeśli inwestycje nie zostaną starannie wdrożone i kontrolowane mogą doprowadzić do problematycznego w skutkach wzrostu zadłużenia niektórych państw w dalszej perspektywie czasu.
\end{abstract}

SŁowa KLuCzowe: Inicjatywa Pasa i Szlaku, Chiny, pułapka zadłużenia, infrastruktura

\section{CHINA'S BELT AND ROAD INITIATIVE AND THE RISK OF INDEBTEDNESS AMONG ITS BENEFICIARIES}

\begin{abstract}
Chinese Belt and Road initiative (BRI) is not only an economic or political project, but also has the potential to transform the international system. The initiative's impact is large from stimulating the financing of infrastructure investments in various countries around the world to the development of new global supply chains. The scientific goal of the article is to analyze the consequences of implementing the initiative. The research problem is included in the following question: does the Belt and Road Initiative contribute to increasing Chinese influence in the world and carries the risk of driving poorer countries into the "debt trap"? The conclusion from the article is that China should create an improved version of the BRI initiative based on a better risk assessment of the current projects. Infrastructure investments, if not carefully implemented and controlled, may lead to consequences, such as increasing the debt of some countries in the long term.
\end{abstract}

KEYWORDS: Belt and Road Initiative, China, debt trap, infrastructure

${ }^{1}$ Adam Mickiewicz University in Poznań; Poland. 


\section{WPROWADZENIE}

Chińska Republika Ludowa dąży do wzmocnienia swojej pozycji jako mocarstwa regionalnego oraz istotnego partnera handlowego. W tym celu przywódca Chin - Xi Jinping, zaproponował projekt, który w języku chińskim nazwano yidai yilu, czyli koncepcję Jednego Pasa i Jednej Drogi (ang. One Belt One Road), obecnie określaną mianem Belt and Road Initiative (BRI), czyli inicjatywą Pasa $i$ Szlaku². Koncepcja ta to strategia rozwoju gospodarczego wykorzystująca nowe projekty infrastrukturalne w celu zintensyfikowania regionalnych i globalnych stosunków handlowych. Przyczynia się ona do zwiększenia wpływów Chin w różnych regionach świata. Chińska inicjatywa to projekt politycznogospodarczy, mający także potencjał do transformacji systemu międzynarodowego. Realizacja infrastrukturalnych projektów w ramach BRI gwarantuje Chinom strategiczne połączenia, których celem jest chociażby zintegrowanie azjatyckiego regionu.

Celem naukowym artykułu jest analiza konsekwencji wdrażania inicjatywy Pasa i Szlaku wobec wybranych państw w niej partycypujących. Problem badawczy sprowadza się do pytania: czy chińska inicjatywa przyczynia się do zwiększenia chińskich wpływów na świecie i niesie za sobą ryzyko wpędzania biedniejszych państw w „pułapkę zadłużenia” poprzez projekty realizowane $\mathrm{w}$ nietransparentny sposób? Wnioskiem płynącym z artykułu jest stwierdzenie, że Chiny powinny stworzyć ulepszoną wersję inicjatywy Pasa i Szlaku opartą o lepszą ocenę ryzyka realizowanych projektów. Inwestycje w infrastrukturę, jeśli nie zostaną starannie wdrażane i kontrolowane, mogą doprowadzić do problematycznego wzrostu zadłużenia niektórych państw w dalszej perspektywie czasu. Autorka w swojej pracy stosuje metodę krytycznej analizy treści.

\section{EWOLUCJA ZNACZENIA CHIŃSKIEJ INICJATYWY PASA I SZLAKU}

Inicjatywa Pasa i Szlaku jest przejawem globalnych ambicji Pekinu ${ }^{3}$. Od momentu jej ogłoszenia jest systematycznie rozszerzana i promowana. Dzieje się to za sprawą zaangażowania się nowych państw oraz intensyfikacji zakresu współpracy, która wykracza obecnie poza kwestie sensu stricte gospodarcze. Ponadto podczas XIX zjazdu Komunistycznej Partii Chin włączono ją do zrewidowanej Konstytucji KPCh jako jeden z głównych celów strategicznych państwa ${ }^{4}$,

\footnotetext{
${ }^{2}$ Pod koniec 2015 r. Komitet Centralny KPCh wydał wytyczne dotyczące standaryzacji thumaczenia nazwy na język angielski żądając, aby termin ,inicjatywa” był stosowany w połączeniu z Pasem i Szlakiem. Ponadto zastrzeżono, aby nie używać w thumaczeniu na język angielski słów: „strategia”, ,projekt”, ,program” i ,,agenda”. Vide: T. Xie, Is China's 'Belt and Road' a Strategy?, https://thediplomat.com/ 2015/12/is-chinas-belt-and-road-a-strategy/ (03.09.2019).

${ }^{3}$ M. Kalwasiński, ,Pas i Szlak” - chińska pułapka kredytowa?,https://www.bankier.pl/wiadomosc/Pas-i-Szlakchinska-pulapka-kredytowa-Analiza-7576219.html (05.09.2019).

${ }^{4} \mathrm{Na}$ podstawie oficjalnych deklaracji przedstawicieli władz państwowych, praktyki polityki zagranicznej oraz bogatej literatury przedmiotu można sporządzić następującą listę celów strategicznych polityki zagranicznej i bezpieczeństwa ChRL: (1) utrzymanie władzy Komunistycznej Partii Chin; (2) ochrona suwerenności państwa i jedności narodowej; (3) zapewnienie korzystnych warunków dla dalszego rozwoju gospodarki; (4) osiągnięcie i utrzymanie pozycji mocarstwowej na arenie międzynarodowej. Vide: E. Medeiros, China's International Behavior. Activism, Opportunism, and Diversification, https://www.rand.org/content/dam/rand/pubs/ monographs/2009/RAND_MG850.pdf (04.09.2019).
} 
co zwiększyło jej znaczenie, zobowiązując tym samym Partię do kontynuacji wdrażania tego projektu ${ }^{5}$. Promowana inicjatywa Pasa $i$ Szlaku w założeniu ma inkluzyjny charakter i elastyczną formułę. Jak na razie nie ma ściśle ukształtowanych reguł i zasad. Chińska dyplomacja podkreśla, że koncepcja realizowana będzie w oparciu o pięć zasad pokojowego współistnienia: wzajemnego poszanowania suwerenności i integralności terytorialnej, wzajemnej nieagresji, wzajemnej nieingerencji w wewnętrzne sprawy zaangażowanych państw, równości i wzajemnej korzyści oraz pokojowego współistnienia ${ }^{6}$. Jak twierdzi Charlie Campbell, korespondent TIME w Azji Wschodniej, koncepcja BRI ma możliwość stania się największą na świecie platformą współpracy regionalnej obejmującą blisko 65\% ludności świata, wytwarzającej łącznie około 40\% światowego $\mathrm{PKB}^{7}$. Oczekiwana kwota inwestycji potrzebnych do zrealizowania ogólnej wizji BRI ma wynieść 8 bln dolarów, z czego finansowane mają być głównie takie dziedziny jak infrastruktura transportowa (lądowa i morska), telekomunikacyjna i energetyczna ${ }^{8}$.

Należy podkreślić, że nie ma oficjalnej mapy ukazującej ostateczny przebieg tego projektu. W dokumencie pod tytułem Vision and Actions on Jointly Building Silk Road Economic Belt and 21st-Century Maritime Silk Road określono, że BRI ma składać się docelowo z sześciu tzw. korytarzy ekonomicznych, które połączą Chiny z kilkoma sąsiednimi regionami. Należą do nich: (1) nowy korytarz gospodarczy mostu euroazjatyckiego; (2) korytarz gospodarczy Chiny-Mongolia-Rosja; (3) korytarz gospodarczy Chiny-Azja Środkowa-Azja Zachodnia; (4) korytarz gospodarczy Chiny-Półwysep Indochiński; (5) korytarz gospodarczy Bangladesz-Chiny-Indie-Myanmar; (6) korytarz gospodarczy Chiny-Pakistan. Z kolei Morski Jedwabny Szlak ma docelowo prowadzić do Morza Śródziemnego poprzez cieśninę Malakka, Ocean Indyjski, Róg Afryki i Morze Czerwone? Jak podkreśla Bogdan Góralczyk, ten drugi komponent to nic innego, jak zapowiedź, że Chiny chcą realizować swoje plany także na morzach i oceanach ${ }^{10}$. Warto nadmienić, że w dokumencie opublikowanym w czerwcu 2017 r. przez Krajową Komisję Rozwoju i Reform ChRL oraz Państwową Administrację Oceaniczną, wyróżniono trzy kolejne połączenia: pas

\footnotetext{
${ }^{5}$ Resolution of the 19th National Congress of the Communist Party of China on the Revised Constitution of the Communist Party of China, http://www.xinhuanet.com/english/2017-10/24/c_136702726.htm (04.09.2019).

${ }^{6}$ Vision and Actions on Jointly Building Silk Road Economic Belt and 21st-Century Maritime Silk Road, http://en.ndrc.gov.cn/newsrelease/201503/t20150330_669367.html (03.09.2019).

${ }^{7}$ Ch. Campbell, China Says It's Building the New Silk Road. Here Are Five Things to Know Ahead of a Key Summit, http://time.com/4776845/china-xi-jinping-belt-road-initiative-obor/ (03.09.2019).

8 J. Hurley, S. Morris, G. Portelance, Examining the Debt Implications of the Belt and Road Initiative from a Policy Perspective,https:/www.cgdev.org/publication/examining-debt-implications-belt-and-roadinitiativepolicy-perspective (03.09.2019).

${ }_{9}^{9}$ M. Kaczmarski, Nowy Jedwabny Szlak: uniwersalne narzędzie chińskiej polityki, https://www.osw.waw.pl/pl/ publikacje/komentarze-osw/2015-02-10/nowy-jedwabny-szlak-uniwersalne-narzedzie-chinskiej-polityki (05.09.2019).

${ }^{10}$ B. Góralczyk, Wielki renesans. Chińska transformacja i jej konsekwencje, Warszawa 2018, s. 379.
} 
ekonomiczny Chiny-Ocean Indyjski-Afryka-Morze Śródziemne, pas ekonomiczny z Chin do Oceanii i Południowego Pacyfiku oraz pas ekonomiczny Chiny-Ocean Arktyczny-Europa ${ }^{11}$.

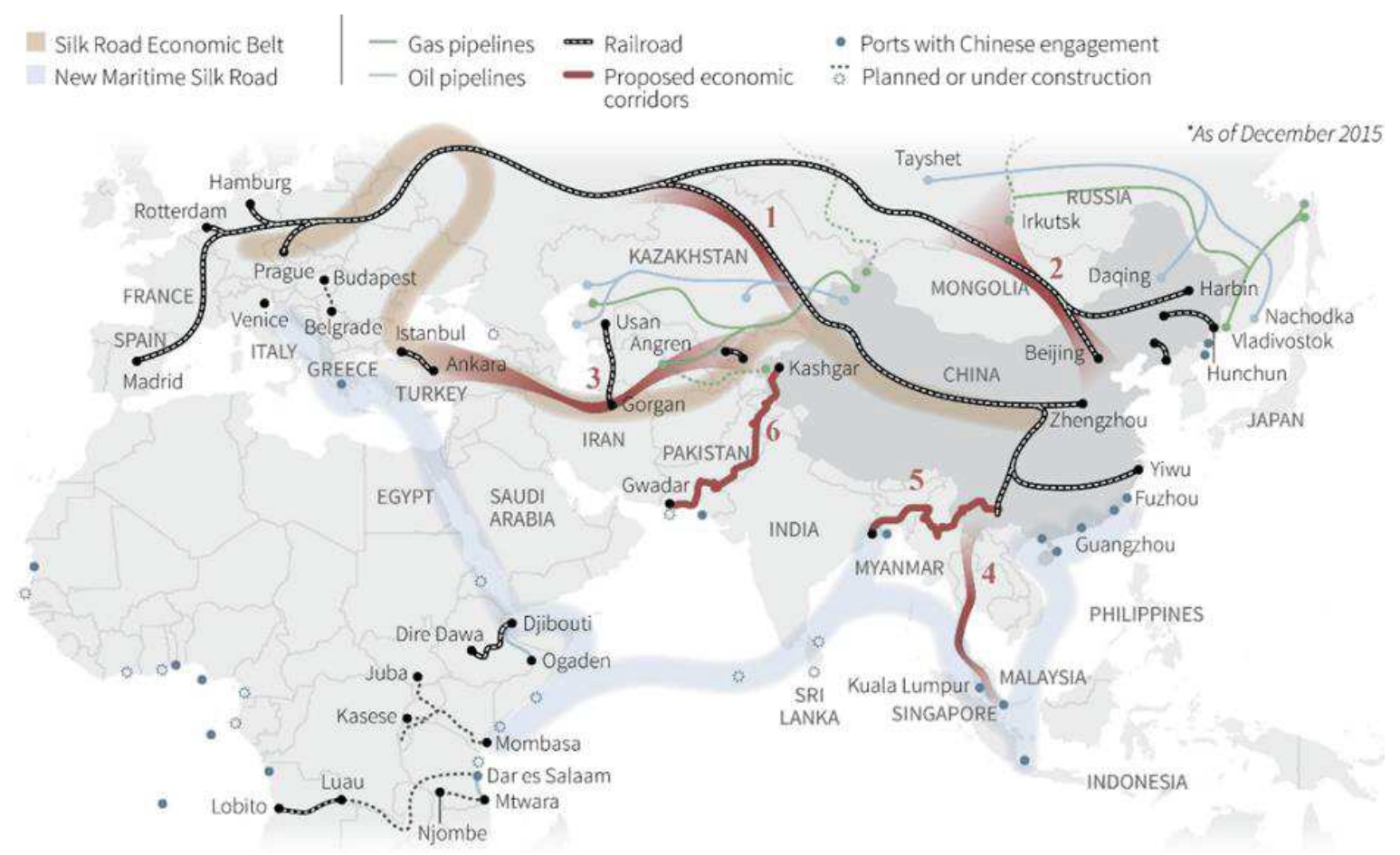

Rysunek 1. Korytarze gospodarcze chińskiej inicjatywy Pasa i Szlaku

Źródło: H. Lu, Ch. Rohr, M. Hafner, A. Knack, China Belt and Road Initiative, https://www.rand.org/content/ dam/rand/pubs/research_reports/RR2600/RR2625/RAND_RR2625.pdf (09.09.2019).

20 czerwca 2017 r. Chińska Narodowa Komisja Rozwoju i Reform oraz Państwowa Administracja Oceaniczna w dokumencie zatytułowanym Vision for Maritime Cooperation under the Belt and Road Initiative przedstawiły dwa dodatkowe szlaki morskie ${ }^{12}$. Pierwszy z nich prowadziłby z Chin przez państwa Oceanii, Ocean Spokojny w kierunku Ameryki Południowej w celu rozszerzenia współpracy z Chile, Argentyną oraz Brazylią, których przedstawiciele pojawili się na pierwszym Forum Pasa i Szlaku ${ }^{13}$. Natomiast drugi z nich, tzw. Polarny Jedwabny Szlak, ma prowadzić z Azji Wschodniej do Europy przez Arktykę ${ }^{14}$. Jak zauważa Tomasz Brańka, znaczenie strategiczne Arktyki w ostatnich latach znacznie wzrosło $^{15}$. Jest to uwarunkowane w dużym stopniu zmianami klimatycznymi i postępującym

11 China proposes 'blue economic passages' for maritime, http://www.chinadaily.com.cn/business/201706/21/content_29825517.htm(05.09.2019).

${ }^{12}$ A. Brona, Chiny proponuja rozszerzenie inicjatywy Pasa i Szlaku, http://pulsazji.pl/2017/06/30/ rozszerzenieinicjatywy-pasa-i-szlaku/ (05.09.2019).

${ }^{13}$ Forum Pasa i Szlaku to międzynarodowa konferencja poświęcona współpracy w ramach chińskiej inicjatywy Pasa i Szlaku. W kwietniu 2019 r. w Pekinie odbyła się ona po raz drugi, pierwsza miała miejsce w 2017 r. Zgodnie $\mathrm{z}$ informacjami strony chińskiej w konferencji wzięło udział niemal 6 tys. uczestników ze 150 krajów oraz przedstawiciele 92 organizacji międzynarodowych.

${ }^{14}$ Full text of the Vision for Maritime Cooperation under the Belt and Road Initiative, http://english.gov.cn/ archive/publications/2017/06/20/content_281475691873460.htm (06.09.2019).

${ }_{15}$ T. Brańka, Polarny Jedwabny Szlak - chińska wizja Arktyki [w:] Księga jubileuszowa dedykowana Profesorowi Zdzisławowi W. Puśleckiemu, A. Stelmach, T. R. Szymczyński, M. Walkowski (red.), Poznań 2018, s. 111. 
ociepleniem się klimatu, co z kolei stwarza nowe możliwości eksploatacji bogatych złóż surowców naturalnych ${ }^{16}$, a także korzystania $\mathrm{z}$ wcześniej niedostępnych arktycznych szlaków komunikacyjnych ${ }^{17}$. Chiny, zauważając potencjalne korzyści energetyczne, handlowe i geopolityczne płynące z uczestnictwa w zarządzaniu Arktyką, w styczniu 2018 r. opublikowały Białą Księgę zatytułowaną Chińska Polityka Arktyczna ${ }^{18}$. Dokument oficjalnie włączył chińską politykę arktyczną do ram inicjatywy BRI poprzez rozbudowę infrastruktury w ramach Polarnego Jedwabnego Szlaku ${ }^{19}$.

Chiny w celu utrzymania stabilnego poziomu wzrostu stawiają na przyszłość gospodarki opartej o technologię cyfrową. Z tego względu Xi Jinping zaproponował również koncepcję Cyfrowego Jedwabnego Szlaku (ang. Digital Silk Road, DSR), która ma docelowo obejmować współpracę i rozwój w gospodarce cyfrowej, sztucznej inteligencji, nanotechnologii, komputerach kwantowych, a także w obszarach takich jak big data, cloud computing oraz smart city. Technologie te mają na celu uzupełnienie infrastruktury powstającej w ramach inicjatywy Pasa iSzlaku oraz wprowadzenie wspólnych standardów technicznych w państwach partycypujących $^{20}$. Inwestując środki finansowe w ambitne inicjatywy krajowe, takie jak Made in China 2025 czy Internet Plus ${ }^{21}$, Chiny nie tylko chcą być potęgą technologiczną, lecz także wdrażać swoich „krajowych przedsiębiorców” w telekomunikację, handel elektroniczny i technologie informacyjne w celu zapewnienia dostępu do niewykorzystanych rynków za granicą. W ramach Cyfrowego Jedwabnego Szlaku Chiny zamierzają rozszerzyć zasięg swojego lokalnego Globalnego Systemu Nawigacji Satelitarnej - Beidou ${ }^{22}$. Jak podkreśla Keshav Kelkar, nie ma lepszego skumulowania realizowanych przez ChRL projektów rozwoju infrastruktury z łącznością cyfrową ${ }^{23}$.

\footnotetext{
${ }^{16}$ Szacuje się, że około $13 \%$ ropy naftowej oraz $30 \%$ gazu ziemnego w tym regionie pozostało jeszcze nieodkrytych. Vide: J. Nakano, China Launches the Polar Silk Road, https://www.csis.org/analysis/china-launches-polar-silk-road (06.09.2019).

${ }^{17}$ Ibidem.

${ }^{18}$ G. Grieger, China's Arctic policy. How China aligns rights and interests, http://www.europarl.europa.eu/ RegData/etudes/BRIE/2018/620231/EPRS_BRI(2018)620231_EN.pdf(06.09.2019).

${ }^{19}$ China's Arctic Policy, http://english.gov.cn/archive/white_paper/2018/01/26/ content_281476026660336.htm (06.09.2019).

${ }^{20}$ J. Chipman, China's long and winding Digital Silk Road, https://www.iiss.org/blogs/analysis/2019/01/chinadigital-silk-road (07.09.2019).

${ }^{21}$ Celem projektu Made in China 2025 jest modernizacja dziesięciu branż zaawansowanych technologii. Natomiast program Internet Plus powstał z myślą o wsparciu sektora cyfrowego w państwach słabo rozwiniętych. Vide: J. Wübbeke, M. Meissner, M. Zenglein, J. Ives, B. Conrad, Made in China 2025. The making of a high-tech superpower and consequences for industrial countries, https://www.merics.org/sites/ default/files/2018-07/MPOC_No.2_MadeinChina2025_web.pdf(06.09.2019).

${ }^{22}$ Beidou jest jednym z czterech głównych globalnych systemów nawigacji satelitarnej (GNSS) na świecie, a także amerykańskim globalnym systemem pozycjonowania (GPS), GALILEO Unii Europejskiej i globalnym systemem nawigacji satelitarnej w Rosji (GLONASS). Ponadto w nadchodzących latach Chiny planują uruchomienie kilkudziesięciu nowych satelitów dla swojego systemu nawigacyjnego Beidou, który jest kontrolowany przez chińskie wojsko, i rozszerzenie zasięgu na wiele krajów BRI. Jak podaje The Economist ponad 30 państw już podpisało umowy o wprowadzeniu systemu Beidou na ich obszar. Vide: C. Smith, A Digital Silk Road, http://www.theworldin.com/article/14433/edition2018digital-silk-roadhttps://worldin2019. economist.com/Chinaseconomy (07.09.2019).

${ }^{23} \mathrm{~K}$. Kelkar, China is building a new Silk Road, and this one is digital, https://www.orfonline.org/expertspeak/43102-from-silk-threads-to-fiber-optics-the-rise-of-chinas-digital-silk-road/ (07.09.2019).
} 


\section{POSTRZEGANIECHIŃSKIEJ INICJATYWY PASA I SZLAKU}

Analiza przeprowadzona przez zespół Bruegel, potwierdziła, że nastroje wobec inicjatywy Pasa i Szlaku uległy pogorszeniu (w 2018 r. oceniane były jeszcze jako średnio pozytywne $)^{24}$. Wszystkie regiony jako całość, z wyjątkiem Azji Południowej, pozytywnie postrzegają BRI ${ }^{25}$. Co ciekawe, nie ma znaczącej różnicy w postrzeganiu BRI między krajami oficjalnie w nim uczestniczącymi oraz tymi, które tego nie robią. Pogarszający się wizerunek BRI jest sygnałem alarmowym dla Chin, które dążą do zwiększenia swojej soft power na całym świecie.

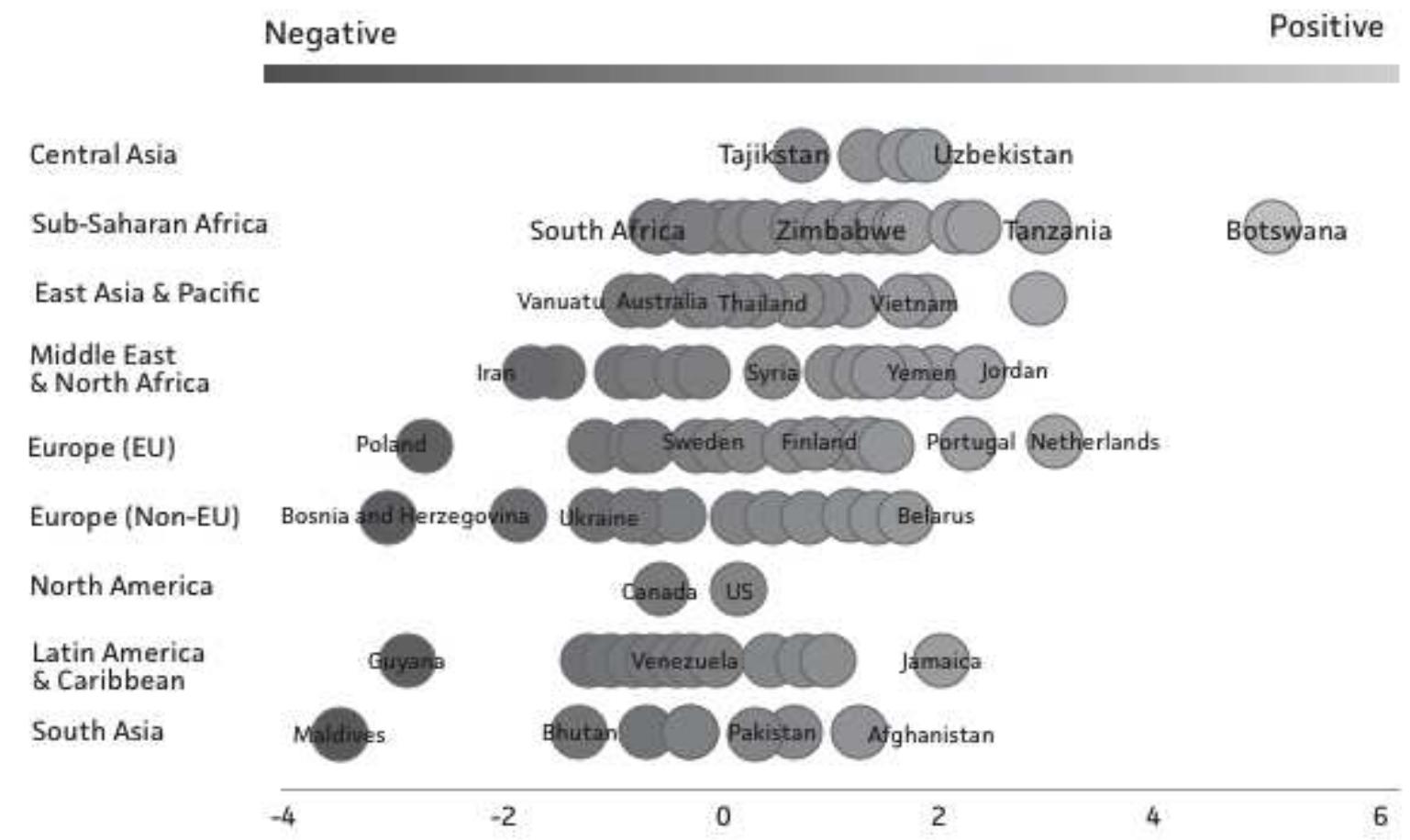

Rysunek 2. Nastroje w stosunku do inicjatywy Pasa i Szlaku z uwzględnieniem regionów świata Źródło: A.G. Herrero, J. Xu, Countries' Perceptions of China's Belt and Road Initiative: a Big Data Analysis, http://bruegel.org/wp-content/uploads/2019/02/WP-2019-01 final.pdf (07.09.2019).

Niektóre państwa stają się coraz bardziej sceptyczne i zaczynają uważać na nadmierną zależność od chińskiego importu i niezrównoważoną strukturę handlu z Chinami. Ponadto problemem jest wzrastająca dynamika zadłużenia w państwach otrzymujących pomoc finansową. Większość beneficjentów inicjatywy z zadowoleniem przyjmuje finansowanie infrastruktury z Chin, ale oczekuje również przejrzystości i uczciwej konkurencji ${ }^{26}$. W tym celu Chiny dokonały ostatnio szeregu strategicznych zmian w odniesieniu do BRI, które jednak w dużym stopniu pozostały niezauważone. Po pierwsze, gwałtownie zwiększyły liczbę

\footnotetext{
${ }^{24}$ A. G. Herrero, J. Xu, Countries' Perceptions..., op. cit.

25 Wyniki raportu zostały oparte o dane z globalnej bazy danych GDELT które obejmują wiadomości telewizyjne, internetowe $\mathrm{i}$ prasę drukowaną z 132 krajów w ponad 100 językach. Vide: Project GDELT, https://www.gdeltproject.org (07.09.2019).

26 A. García-Herrero,Has the Belt and Road Initiative Become a Political Liability for China?, https://www.brinknews.com/has-the-belt-and-road-initiative-become-a-political-liability-for-china/ (07.09.2019).
} 
krajów partycypujących do 150. Po drugie, próbują wykorzystać do swych działań powołane przez siebie instytucje, takie jak Azjatycki Bank Inwestycji Infrastrukturalnych. Tego typu działania pozwalają Chinom zachować najwyższą kontrolę nad kluczowymi projektami, ale jednocześnie oferują miejsce dla innych krajów rozwiniętych, w szczególności krajów europejskich.

\section{SYSTEM FINANSOWANIA INWESTYCJI W RAMACH BRI}

Równolegle z rozwojem projektu Pasa i Szlaku Chiny rozpoczęły inicjowanie nowych instytucji finansowych. W celu realizacji założeń i projektów został powołany w 2014 r. specjalny Fundusz Jedwabnego Szlaku o pierwotnej wartości 40 mld dolarów. Fundusz ten typu private equity - bezpośrednio podlega Chińskiemu Bankowi Centralnemu. Wykorzystuje on przede wszystkim kapitał krajowy płynący z chińskich rezerw walutowych (65\%), China Investment Corporation (15\%), China Exim Bank (15\%) oraz China Development Bank $(5 \%)^{27}$. Dość szybko okazało się, że aktywne środki są niewystarczające. Dlatego podczas ceremonii otwarcia pierwszego wielostronnego szczytu BRI w maju 2017 r. Xi Jinping zadeklarował, że Chiny przekażą dodatkowe 14,5 mld dolarów (100 mld RMB) na rzecz Funduszu Jedwabnego Szlaku ${ }^{28}$.

Kolejnym źródłem finansowania chińskiej inicjatywy jest Azjatycki Bank Inwestycji Infrastrukturalnych (ang. Asian Infrastructure Investment Bank, AIIB), który został utworzony 24 października 2014 r. AIIB to pierwszy multilateralny bank rozwojowy (ang. Multilateral Development Bank, MDB) zaproponowany przez Chiny, którego kluczowym celem jest zapewnienie finansowego wsparcia poprzez udzielanie preferencyjnych kredytów przede wszystkim dla budowy infrastruktury w Eurazji ${ }^{29}$. Jego kapitał założycielski to 100 mld dolarów. Pierwszy kredyt na przedsięwzięcia w ramach BRI (10,5 mld dolarów), przeznaczono na szybką kolej chińską prowadzącą przez całe terytorium Tajlandii. Kolej ta docelowo ma zmierzać do Singapuru. Obecnie Azjatycki Bank Inwestycji Infrastrukturalnych liczy 97 państw oraz 27 potencjalnych członków, którzy w niedalekim czasie mogą również przystąpić do $\mathrm{AIIB}^{30}$. Do największych regionalnych akcjonariuszy AIIB należą: Chiny (30,9\%), Indie (8,7\%), Rosja (6,8\%), Korea Południowa (3,9\%) oraz Australia (3,8\%). Do piątki największych nieregionalnych akcjonariuszy, posiadających odpowiednio wysokie udziały w AIIB, należą natomiast państwa Unii Europejskiej takie jak: Niemcy (4,7\%),

\footnotetext{
${ }^{27}$ Research for TRAN Committee: The new Silk Route - opportunities and challenges for EU transport, http://www.europarl.europa.eu/RegData/etudes/STUD/2018/585907/IPOL_STU(2018)585907_EN.pdf(07.09.2019).

${ }^{28}$ Full text of President Xi's speech at opening of Belt and Road forum, http://www.xinhuanet.com/english/201705/14/c_136282982.htm (07.09.2019).

29 Vide: P. Tomaszewska, S. Tomaszewska, Raport: Finansowanie i inwestycje, https://drive.google.com/ file/d/1uWTYVSb7MVjB9TDYObCBWdfXCS1C_wxu/view (08.09.2019).

${ }_{30}$ Presentation about Asian Infrastructure Investment Bank, https://www.aiib.org/en/treasury/_common/ _download/IP-Red-August_2019.pdf (08.09.2019).
} 
Francja (3,5\%), Wielka Brytania (3,2\%), Włochy $(2,7 \%)$ i Hiszpania $(1,8 \%)$. Polska znalazła się na ósmym miejscu; posiada $0,9 \%$ udziałów w $\mathrm{AIIB}^{31}$.

Początkowo obawiano się, że AIIB będzie konkurentem dla istniejących już MDB, chociażby w odniesieniu do projektów gotowych do realizacji. Jednakże dość szybko Jin Liqun, oświadczył, że AIIB będzie aktywnie współpracować z innymi instytucjami, przyjmując strategię współdziałania $\mathrm{w}$ zakresie finansowania projektów ${ }^{32}$. Wobec tego AIIB szybko przystąpił do podpisywania umów o współpracy. Pierwszą umowę zawarł 13 kwietnia 2016 r. z Bankiem Światowym w celu współfinansowania projektów w Indonezji, Pakistanie, Azerbejdżanie, Indiach, Tadżykistanie, Turcji i na Filipinach o łącznej wartości 17,8 mld dolarów $^{33}$. 2 maja 2016 r. podpisano umowę z Azjatyckim Bankiem Rozwoju w celu współfinansowania inwestycji infrastrukturalnych między innymi w Pakistanie, Bangladeszu, Birmie, Gruzji, Azerbejdżanie oraz Indiach. Kolejne umowy zostały zawarte z europejskimi bankami rozwoju w tym z Europejskim Bankiem Odbudowy i Rozwoju oraz Europejskim Bankiem Inwestycyjnym w celu współfinansowania projektów infrastrukturalnych w Tadżykistanie i Azerbejdżanie ${ }^{34}$.

Do instytucji wspierających finansowanie projektów w ramach chińskiej inicjatywy należy także Nowy Bank Rozwoju (ang. New Development Bank, NDB). Został on powołany w 2014 r. przez państwa grupy BRICS w celu wspierania inwestycji infrastrukturalnych i zrównoważonego rozwoju w Brazylii, Rosji, Indiach, Chinach, Republice Południowej Afryki oraz innych wschodzących gospodarkach ${ }^{35}$. Obecnie kapitał założycielski banku wynosi 100 mld dolarów. Zgodnie z danymi zamieszczonymi na oficjalnej stronie internetowej New Development Bank zatwierdził realizację 30 projektów o łącznej wartości 8 mld dolarów ${ }^{36}$. K.V. Kamath, prezes NDB, w jednym z wywiadów powiedział, że do końca 2021 r. bank przeznaczy 40 mld dolarów na realizację około 100 projektów ${ }^{37}$. Chociaż Nowy Bank Rozwoju nie został utworzony w celu wspierania projektów realizowanych w ramach BRI, to skupienie się na zachęcaniu do większej współpracy finansowej i rozwojowej oznacza, że jest on w pewnym stopniu pośrednio powiązana z celami chińskiej inicjatywy. Na obecną chwilę NDB finansuje projekty infrastrukturalne przede wszystkim w państwach należących do grupy BRICS.

Podkreślenia wymaga również fakt, że poza bankami o międzynarodowym charakterze Chiny będą nadal finansować większość inwestycji dzięki dwustronnym preferencyjnym pożyczkom udzielanym przez ich krajowe banki-giganty, takie jak: China Development Bank, Bank of China, czy China Exim Bank. Zheng Zhijie, prezes China Development Bank, podczas

\footnotetext{
${ }^{31}$ Ibidem, s. 8.

${ }^{32}$ S. Fleming, AIIB and World Bank to work on joint projects, https://www.ft.com/content/3995f790-01b0-11e6ac98-3c15a1aa2e62 (08.09.2019).

${ }^{33}$ Presentation about Asian ..., op. cit., s. 39.

${ }^{34}$ Ibidem.

${ }^{35}$ About New Development Bank, https://www.ndb.int/about-us/ (08.09.2019).

${ }^{36}$ Projects, https://www.ndb.int/projects/list-of-all-projects/(10.09.2019).

37 BRICS New Development Bank on Course to Lend US\$40 Billion in Green Infrastructure Projects, https:/www.silkroadbriefing.com/news/2019/03/08/brics-new-development-bank-course-lend-40-billion-greeninfrastructure-projects/(10.09.2019).
} 
Boao Forum for Asia w 2019 r. powiedział, że CDB przeznaczył ponad 190 mld dolarów na ponad 600 projektów infrastrukturalnych od momentu zainicjowania chińskiej inicjatywy ${ }^{38}$. Natomiast Zhang Qingsong, prezes China Exim Bank, stwierdził, że jego instytucja udzieliła pożyczek preferencyjnych na łączną sumę przekraczającą 1 bilion juanów, czyli 149 mld dolarów w celu sfinansowania 1800 projektów infrastrukturalnych ${ }^{39}$.

Jedną z charakterystycznych cech BRI jest gotowość chińskich instytucji do wsparcia projektów. Projekty zaplanowane do realizacji w ramach tej inicjatywy są bardzo kapitałochłonne i wymagają stałego finansowania. Niestety wiele z państw partnerskich BRI to państwa o średnich bądź niskich dochodach. Istnieje więc ryzyko, że będą one uzależnione od finansowania zewnętrznego w celu terminowego i pomyślnego wykonania zaplanowanych projektów. W przeciwieństwie do planu Marshalla wsparcie finansowe w ramach tej koncepcji udzielane jest poprzez pożyczki, a nie granty ${ }^{40}$. Banki takie jak China Development Bank (CDB), Export-Import Bank of China (China Exim Bank) i Agriculture Development Bank of China (ADBC) zobowiązują się do finansowania projektów w ramach BRI na ponad 440 mld dolarów ${ }^{41}$, z czego 90 mld dolarów zostało już bezpośrednio zainwestowanych w projekty ${ }^{42}$. Umowy finansowe zostały w dużej mierze skonstruowane jako transakcje dwustronne bez udziału instytucji wielostronnych i odpowiadających im ram oceny ekonomicznej. Krótko mówiąc projekty realizowane $\mathrm{w}$ ramach BRI nie wiążą się z warunkami i restrykcjami, które są ustanowione przez takie instytucje jak Bank Światowy, Azjatycki Bank Rozwoju i inne źródła finansowania wielostronnego. Tego typu finansowanie już doprowadziło do dyfuzji chińskich sektorów finansowych. Dwustronne relacje między instytucjami finansowymi doprowadziły do rozwoju sieci bankowych jedenastu chińskich banków działających w dwudziestu ośmiu oddziałach państw partycypujących w BRI, podczas gdy pięćdziesiąt banków z dwudziestu dwóch takich państw rozpoczęło swoją działalność w Chinach $^{43}$. Oprócz pożyczek państwowych, instrumenty finansowe wykorzystywane do rozwoju korytarzy gospodarczych obejmują również pożyczki preferencyjne, kredyty komercyjne i inwestycje kapitałowe. Na przykład chiński Pakistan Economic Corridor (CPEC), flagowa inwestycja BRI, ma na swoim koncie inwestycje o wartości 19 mld dolarów, z których ponad 60\% stanowią komercyjne pożyczki i inwestycje kapitałowe ${ }^{44}$.

\footnotetext{
38 K. Yao, China Development Bank provides over $\$ 190$ billion for Belt and Road projects, https://www.reuters.com/article/us-china-finance-cdb-bri/china-development-bank-provides-over-190-billionfor-belt-and-road-projects-idUSKCN1R8095 (10.09.2019).

${ }^{39}$ China's Exim Bank provides more than $\$ 149$ bln for Belt and Road projects, https://www.reuters.com/ article/china-bank-beltandroad/chinas-eximbank-provides-more-than-149-bln-for-belt-and-road-projectsidUSL3N2202TI (10.09.2019).

40 D. Gerstel, It's a (Debt) Trap! Managing China-IMF Cooperation Across the Belt and Road, https://www.csis.org/npfp/its-debt-trap-managing-china-imf-cooperation-across-belt-and-road (11.09.2019).

${ }_{41}$ BRI is not debt a trap, says finance minister, https://www.asiatimes.com/2019/04/article/bri-is-not-debt-trapsays-finance-minister-liu-kun/ (11.09.2019).

${ }_{22}$ A. Romann, Who will benefit from China's Belt and Road Initiative?, https://www.aljazeera.com/news/ 2019/04/benefit-china-belt-road-initiative-190427131051786.html (11.09.2019).

${ }^{43}$ BRI is not debt a trap ..., op. cit.

${ }^{44}$ U. Nadeem, Belt \& Road..., op. cit.
} 


\section{CHIŃSKA INICJATYWA PASA I SZLAKU}

\section{- DYPLOMACJĄ PULAPKI ZADLUŻENIA?}

Niedookreślone standardy finansowania chińskiego projektu budzą wiele pytań i wątpliwości. Finansowanie infrastruktury, które często łączy się z udzielaniem pożyczek państwom lub korzystaniem z gwarancji państwowej, może stworzyć wyzwania dla ich dalszej stabilności. W marcu 2019 r. w Pekinie odbyło się drugie Forum Pasa i Szlaku, które zgromadziło setki wyższych rangą przywódców z wielu państw świata. Reprezentantami z trzydziestu siedmiu krajów byli szefowie państw i rządów, w tym prezydent Federacji Rosyjskiej - Władimir Putin, premier Włoch - Giuseppe Conte, oraz premier Pakistanu - Imrana Chan. Podczas gdy wielu w Chinach świętowało sukces zbliżenia się tego szeregu państw partnerskich inicjatywy Pasa i Szlaku, niektóre ważne potęgi regionalne, w tym Turcja i Indie, poddały w wątpliwości ekonomiczne i polityczne skutki dotyczące koncepcji. Podkreślając, że poziom zadłużenia krajów inwestujących w ogromne projekty infrastrukturalne wzrośnie, a Chiny są jednym z głównych wierzycieli tych inwestycji ${ }^{45}$.

Analitycy z amerykańskiego think tanku Center for Global Development uważają, że największym zagrożeniem płynącym z inicjatywy BRI jest wystąpienie kryzysów zadłużeniowych w państwach o niskim poziomie rozwoju gospodarczego ${ }^{46}$. Eksperci zwrócili uwagę na obecny poziom długu publicznego oraz zobowiązania partycypujących państw wobec Chin. Następnie policzyli, jak zwiększą się te wartości, jeżeli dojdzie do realizacji ogłoszonych już, a nieuwzględnionych w powyższych danych projektów w ramach inicjatywy Pasa i Szlaku. Sprawdzili w ten sposób, które z 68 państw uczestniczących w inicjatywie są szczególnie zagrożone wpadnięciem w „pułapkę zadłużenia”. Na wstępie odrzucili 35 państw posiadających zadowalający rating inwestycyjny (na tym etapie odpadła m.in. Polska). Wykluczono także 8 państw posiadających bardzo niski poziom długu publicznego i pozytywną ocenę MFW lub Banku Światowego. W analizie pominięto również Syrię i Jemen ze względu na wojny toczące się na ich obszarze. Według raportu projekty infrastrukturalne związane z inicjatywą Pasa i Szlaku mogą doprowadzić do kryzysów w 23 państwach ${ }^{47}$. Do państw o największym ryzyku wpadnięcia w „pułapkę zadłużenia” zaliczono: Dżibuti, Malediwy, Laos, Czarnogórę, Mongolię, Tadżykistan, Kirgistan i Pakistan ${ }^{48}$.

\footnotetext{
${ }^{45}$ D. Gerstel, It's a (Debt) Trap!..., op. cit.

${ }^{46}$ J. Hurley, S. Morris, G. Portelance, Examining the Debt..., op. cit.

${ }^{47}$ Ibidem.

${ }^{48}$ Ibidem.
} 


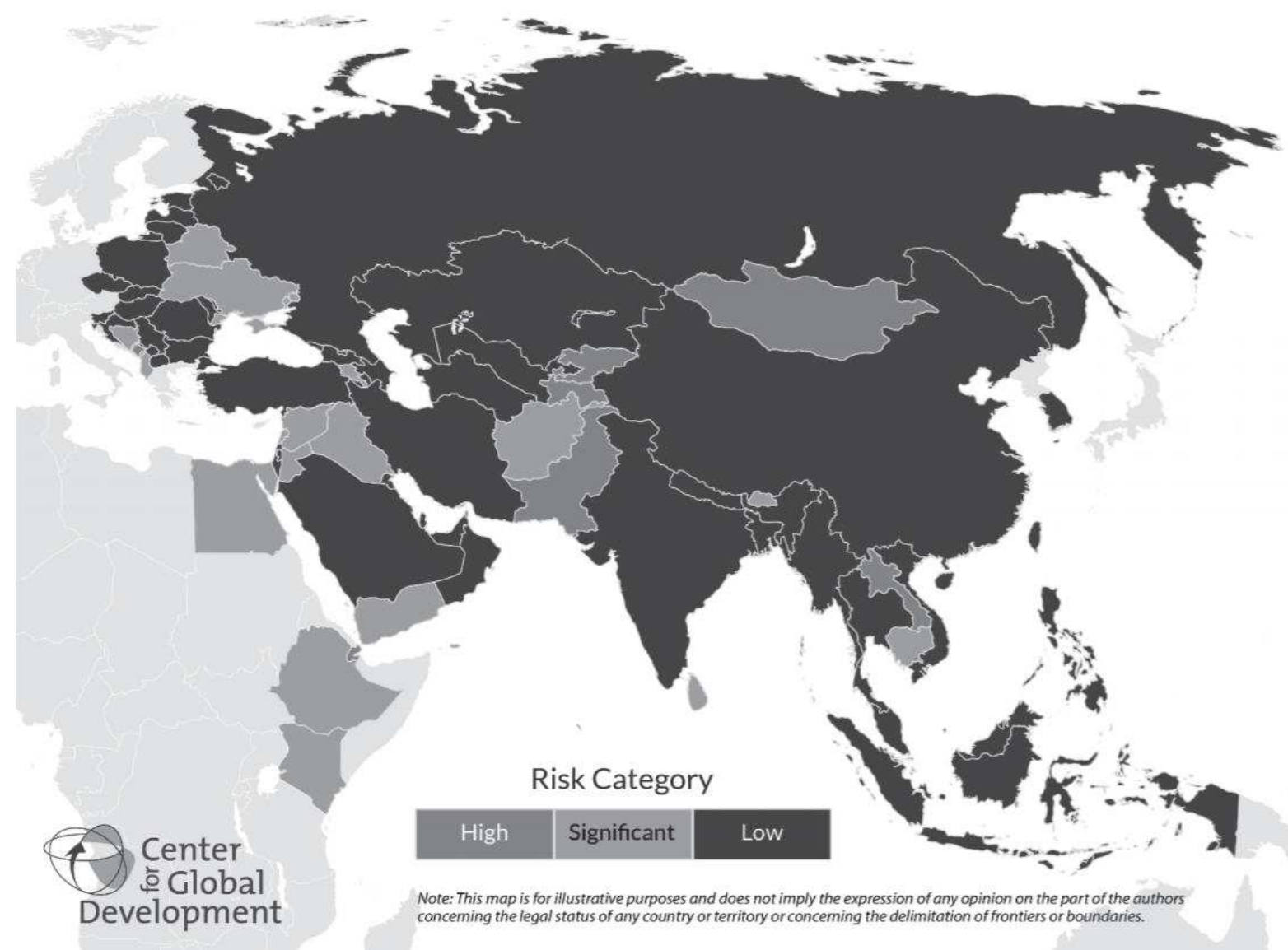

Rysunek 3. Państwa zagrożone ryzykiem zadłużeniowym związanym z realizacją BRI Źródło: J. Hurley, S. Morris, G. Portelance, Examining the Debt..., op. cit.

Warto byłoby się wspomnieć chociaż o kilku z wymienionych powyżej państw. Dżibuti to miejsce, gdzie powstała pierwsza zagraniczna baza wojskowa chińskiej armii na mocy umowy podpisanej w styczniu 2016 r. Najnowszy raport MFW ukazuje, że dług publiczny Dżibuti w ciągu zaledwie dwóch lat wzrósł z 50 do $85 \% \mathrm{PKB}^{49}$. Według wielu doniesień Chiny przeznaczyły około 1,4 mld dolarów na finansowanie dużych projektów infrastrukturalnych w tym państwie (kwota ta stanowi $75 \%$ PKB kraju) ${ }^{50}$. W Dżibuti mają powstać m.in. dwa lotniska, port oraz terminal naftowy ${ }^{51}$.

Kolejnym przykładem państwa zagrożonego kryzysem zadłużeniowym jest Laos, który należy do najbiedniejszych krajów Azji Południowo-Wschodniej, choć szybko się rozwija. Wzrost jego PKB w ciągu ostatniej dekady wyniósł około 8\%. Od 2013 r. MFW wyraża wątpliwości co do jego zdolności do zwrotu zadłużenia związanego z realizacją projektu budowy szybkiej kolei łączącej Laos z Chinami, którego wartość przekroczyła 6,5 mld dolarów ${ }^{52}$.

\footnotetext{
${ }^{49}$ J. Hurley, S. Morris, G. Portelance, Examining the Debt Implications ..., op. cit., s. 16-17.

50 E. Downs, J. Becker, China's Presence in Djibouti is Not a National Security Threat-Yet, https://nationalinterest.org/feature/chinas-presence-djibouti-not-national-security-threat $\%$ E2\%80\%94yet-22498 (12.09.2019).

${ }^{51}$ Z.W. Puślecki, Unia Europejska - Chiny, Poznań 2019, s. 469.

${ }^{52}$ Staff Report for the 2016 Article IV Consultation - Debt Sustainability Analysis, https://www.imf.org/ /media/ Files/Publications/CR/2017/cr1739.ashx (12.09.2019).
} 
Pod koniec 2017 r. Malediwy i Chiny zawarły umowę o wolnym handlu i memorandum o współpracy w ramach inicjatywy Pasa i Szlaku ${ }^{53}$. Tym samym łańcuch wysp na Oceanie Indyjskim został wciągnięty w walkę o wpływy między Indiami a Chinami, które zainwestowały miliony dolarów za rządów prochińskiego byłego przywódcy Abdulli Yameena ${ }^{54}$. Polityka Chińczyków na Malediwach łączy się z budową chińsko-pakistańskiego korytarza ekonomicznego oraz budową portu w Gwadarze. Chiny fundują ponadto na wyspach wielkie projekty infrastrukturalne, m.in. Most Przyjaźni łączący Male z wyspą Hulhule oraz projekt mieszkaniowy tysiąca apartamentów na wyspie Hulhumale ${ }^{55}$. Obecnie rządząca Malediwska Partia Demokratyczna obawia się, że zadłużenie ich państwa wobec Chin może sięgnąć nawet 3 mld dolarów ${ }^{56}$.

Wspomnieć należy również o najbardziej nagłośnionej przez media sytuacji Sri Lanki. Choć akurat to państwo nie zostało wymienione w najbardziej zagrożonej ósemce, to najdotkliwiej odczuło konsekwencje wynikające $\mathrm{z}$ zapożyczenia się w chińskich bankach. W wyniku niemożliwości spłaty pożyczek o łącznej wartości 8 mld dolarów przeznaczonych na rozbudowę portu w Hambantota prezydent Sri Lanki - Maithripali Siriseny, zatwierdził konwersję zadłużenia na 99-letnią umowę na zarządzanie portem przez chińską firmę China Merchants Port Holdings ${ }^{57}$. Przejęcie przez Chiny portu Hambantota w Sri Lance w ramach swapu obsługi zadłużenia jest wymieniane jako główny przykład obaw przed zajęciem aktywów. W momencie przejęcia portu Hambantota zadłużenie zewnętrzne Sri Lanki wyniosło 46,5 mld USD, z czego Chinom były one dłużne mniej niż 10\% tej kwoty ${ }^{58}$.

Porównując ze sobą wymienione powyżej przykłady państw obarczonych ryzykiem związanym $\mathrm{z}$ wystąpieniem kryzysu zadłużeniowego, można wskazać na dwie charakterystyczne cechy, które powodują, że są one do siebie podobne. Kluczowe jest ich położenie strategiczne. Dżibuti jest bowiem położone w bardzo dogodnym miejscu, na przecięciu głównych szlaków morskich łączących Europę z Azją. Port Hambantota stanowi z kolei ważny punkt w strategii „sznura pereł”, ponieważ znajduje się pośrodku Oceanu Indyjskiego, w połowie drogi między Morzem Południowochińskim a Morzem Czerwonym. Laos to państwo tranzytowe położone w centrum Półwyspu Indochińskiego, które jest bogate w surowce naturalne. Warto również zwrócić uwagę, że te trzy państwa łączy niskie tempo rozwoju gospodarczego i w związku $\mathrm{z}$ tym posiadają one zapotrzebowanie na inwestycje

\footnotetext{
${ }^{53}$ China's rising influence in Maldives cause for concern, https://www.nationthailand.com/opinion/30339628 (15.09.2019).

${ }^{54}$ China says Maldives is not 'mired in a Chinese debt trap, https://www.channelnewsasia.com/news/asia/chinasays-maldives-is-not--mired-in-a-chinese-debt-trap--11929910 (15.09.2019).

${ }_{55}$ B. Oleszko-Pyka, Stan wyjątkowy na Malediwach, czyli wielka polityka Indii, Chin oraz USA, http://pulsazji.pl/2018/03/05/stan-wyjatkowy-malediwach-czyli-wielka-polityka-indii-chin-oraz-usa/ (15.09.2019).

${ }_{56}$ Maldives is estimated to have a debt of USD 3 billion to China, Corporate Maledives, https://corporatemaldives.com/maldives-is-estimated-to-have-a-debt-of-usd-3-billion-to-china/ (15.09.2019),

57 S. Aneez, China's 'Silk Road' push stirs resentment and protest in Sri Lanka, https:/www.reuters.com/ article/us-sri-lanka-china-insight/chinas-silk-road-push-stirs-resentment-and-protest-in-sri-lankaidUSKBN15G5UT (15.09.2019).

58 D. Brautigam, Is China the World's Loan Shark?, https://www.nytimes.com/2019/04/26/opinion/china-beltroad-initiative.html (15.09.2019).
} 
infrastrukturalne. Jak podkreśla Maciej Kalwasiński, nie wiadomo, jakie naprawdę są koszty zaplanowanych projektów ani czy będą one w ogóle realizowane. Problematyczna jest natomiast transparentność działań w ramach inicjatywy. Nie wiadomo, jakie będą kolejne inwestycje i jaki będzie ich koszt. Jest też wiele zmiennych niezależnych, tj. tempo wzrostu gospodarczego, kurs dolara, kurs juana, wysokość stóp procentowych czy inflacja ${ }^{59}$.

Można także odnaleźć pozytywne opinie o działaniu chińskiej pomocy będącej wynikiem projektów inwestycyjnych powiązanych z BRI. Przykładowo w Senegalu nastąpił silny wzrost gospodarczy o ponad 6 procent w każdym z ostatnich czterech lat, który był częściowo wspierany przez projekty inwestycyjne powiązane z BRI, w tym budowę nowej autostrady łączącej lotnisko $\mathrm{z}$ trzema dużymi miastami ${ }^{60}$. W badaniu stwierdzono, że choć problemy $\mathrm{z}$ zadłużeniem są powszechne wśród państw otrzymujących wysoki poziom finansowania na szybki rozwój infrastruktury, to konfiskata aktywów przez Chiny jest zjawiskiem niezwykle rzadkim. Mimo że wierzyciel cieszy się dość silną pozycją, negocjacje w dużej mierze przynoszą korzyści państwom przystępującym do pożyczek, oferując różne sposoby późniejszego uregulowania zadłużenia. Należy jednak zauważyć, że były to wstępne wyniki badania, a analiza empiryczna nie pozwala przewidzieć przyszłych metod zarządzania długiem w ramach $\mathrm{BRI}^{61}$. Z kolei badania przeprowadzone przez China Africa Research Initiative (CARI) pokazują, że szacunki MFW dotyczące siedemnastu państw afrykańskich o niskich dochodach $\mathrm{w}$ obliczu kłopotów z zadłużeniem lub na jego skraju nie były spowodowane pożyczkami udzielonymi przez ChRL. To większość światowych banków oraz instytucji finansowych udzieliło kredytów i pozwoliło na duże zadłużenia państw afrykańskich, w szczególności w Mozambiku - Credit Suisse lub w Czadzie - anglo-szwajcarski gigant wydobywczy Glencore. Tylko w Dżibuti, Republice Konga i Zambii chińskie pożyczki stanowiły połowę lub więcej długu publicznego tych państw ${ }^{62}$.

\section{Podsumowanie}

Perspektywy sukcesu BRI są zależne od wielu niewiadomych, w tym możliwości powstania oporu zagranicznego, wewnętrznych problemów gospodarczych Chin, zawirowań politycznych, problemów środowiskowych czy starzenia się społeczeństwa spowodowanego polityką jednego dziecka wprowadzoną w 1979 r. Bez wątpienia realizacja projektów w ramach chińskiej inicjatywy pozwala na większą obecność Chin szczególnie w regionie Azji Południowej i Środkowej oraz w Rogu Afryki. Podsumowując przejrzystość finansowania infrastruktury w ramach inicjatywy Pasa i Szlaku ma kluczowe znaczenie dla regionalnej

\footnotetext{
${ }^{59}$ M. Kalwasiński, Pas i Szlak..., op. cit.

${ }^{60}$ A. Kratz, A. Feng, L. Wright, New Data on the "Debt Trap” Question, https://rhg.com/research/new-data-onthe-debt-trap-question/ (16.09.2019).

${ }^{61}$ Turkey stays away from China's Belt and Road summit citing debt-trap diplomacy and Uighur concerns, https://intellinews.com/turkey-stays-away-from-china-s-belt-and-road-summit-citing-debt-trap-diplomacy-anduighur-concerns-160249/ (16.09.2019).

${ }^{62}$ D. Brautigam, Is China ..., op. cit.
} 
stabilności gospodarczej. Jak na razie niewiele jest twardych dowodów na to, że Chiny rzeczywiście przyczyniają się do powstawania kryzysów zadłużeniowych w tych państwach. Istnieją jednak uzasadnione obawy co do tego, w jaki sposób państwa partycypujące w BRI korzystają z elastyczności fiskalnej, na jaką Chiny im przyzwalają. Brak przejrzystości w zakresie finansowania inicjatywy to jeden z głównych powodów takich spekulacji. Międzynarodowy Fundusz Walutowy wielokrotnie i wyraźnie kwestionował nieprzejrzyste udzielanie pożyczek i domagał się większej transparentności, aby zniwelować asymetrię informacyjną wokół wzrastających chińskich wpływów. Uszczegółowienie informacji na temat projektów BRI z pewnością pomogłoby przeciwdziałać narracji o powstającej „pułapce zadłużenia”. Opracowanie transparentnych ram oceny ekonomicznej państw partycypujących w koncepcji umożliwiłoby sporządzenie trafniejszych profili ryzyka zaangażowanych stron. Doprowadziłoby to do budowania wielostronnego zaufania i przyczyniłoby się do podejmowania bardziej świadomych decyzji zainteresowanych stron. Jeśli inwestycje nie zostaną starannie wdrożone i kontrolowane, mogą doprowadzić do problematycznego w skutkach wzrostu zadłużenia niektórych państw w dalszej perspektywie czasu.

\section{BIBLIOGRAFIA}

About New Development Bank. W https:/www.ndb.int/about-us/.

Aneez Shihar. 2017. China's 'Silk Road' push stirs resentment and protest in Sri Lanka. W https://www.reuters.com/article/us-sri-lanka-china-insight/chinas-silk-road-pushstirs-resentment-and-protest-in-sri-lanka-idUSKBN15G5UT.

Brańka Tomasz. 2018. Polarny Jedwabny Szlak-chińska wizja Arktyki. W Księga jubileuszowa dedykowana Profesorowi Zdzisławowi W. Puśleckiemu. Poznań: Wydawnictwo Wydawnictwo Naukowe WNPiD UAM, 111-123.

Brautigam Deborah. 2019. Is China the World's Loan Shark? W https://www.nytimes.com/ 2019/04/26/opinion/china-belt-road-initiative.html.

BRI is not debt a trap, says finance minister. W https://www.asiatimes.com/2019/ 04/article/bri-is-not-debt-trap-says-finance-minister-liu-kun/.

BRICS New Development Bank on Course to Lend US\$40 Billion in Green Infrastructure Projects. W https://www.silkroadbriefing.com/news/2019/03/08/brics-new-develop ment-bank-course-lend-40-billion-green-infrastructure-projects/.

Brona Adrian. 2017. Chiny proponują rozszerzenie inicjatywy Pasa i Szlaku. W http://pulsazji.pl/2017/06/30/rozszerzenie-inicjatywy-pasa-i-szlaku/.

Campbell Charlie. 2017. China Says It's Building the New Silk Road. Here Are Five Things to Know Ahead of a Key Summit. W http://time.com/4776845/china-xi-jinping-beltroad-initiative-obor/.

China proposes 'blue economic passages' for maritime. W http://www.chinadaily.com.cn/ business/2017-06/21/content_29825517.htm.

China says Maldives is not 'mired in a Chinese debt trap. Whttps://www.channelnew sasia.com/news/asia/china-says-maldives-is-not--mired-in-a-chinese-debt-trap--11929910. 
China's Arctic Policy. W http://english.gov.cn/archive/white_paper/2018/01/26/ content_ 281476026660336.htm.

China's Exim Bank provides more than $\$ 149$ bln for Belt and Road projects. W https://www.reuters.com/article/china-bank-beltandroad/chinas-eximbank-providesmore-than-149-bln-for-belt-and-road-projects-idUSL3N2202TI.

China's rising influence in Maldives cause for concern. W https://www.nationthailand.com/ opinion/30339628.

Chipman John. 2019. China's long and winding Digital Silk Road. W https://www.iiss.org/ blogs/analysis/2019/01/china-digital-silk-road.

Downs Erica, Becker Jeff. 2017. China's Presence in Djibouti is Not a National Security Threat-Yet. W https://nationalinterest.org/feature/chinas-presence-djibouti-notnational-security-threat $\%$ E2\%80\%94yet-22498.

Fleming Sam. 2016. AIIB and World Bank to work on joint projects. W https://www.ft.com/ content/3995f790-01b0-11e6-ac98-3c15a1aa2e62.

Full text of President Xi's speech at opening of Belt and Road forum. W http://www.xinhuanet.com/english/2017-05/14/c_136282982.htm.

Full text of the Vision for Maritime Cooperation under the Belt and Road Initiative. W http://english.gov.cn/archive/publications/2017/06/20/content_281475691873460.htm.

García-Herrero Alicia. 2019. Has the Belt and Road Initiative Become a Political Liability for China? W https:/www.brinknews.com/has-the-belt-and-road-initiative-become-apolitical-liability-for-china/.

Gerstel Dylan. 2018. It's a (Debt) Trap! Managing China-IMF Cooperation Across the Belt and Road. W https://www.csis.org/npfp/its-debt-trap-managing-china-imf-cooperationacross-belt-and-road.

Góralczyk Bogdan. 2018. Wielki renesans. Chińska transformacja i jej konsekwencje. Warszawa: Dialog.

Grieger Gisela. 2018. China's Arctic policy. How China aligns rights and interests. W http://www.europarl.europa.eu/RegData/etudes/BRIE/2018/620231/EPRS_BRI(2018 620231_EN.pdf.

Herrero Alicia Garcia, Xu Jianwei. 2019. Countries' Perceptions of China's Belt and Road Initiative: a Big Data Analysis. W http://bruegel.org/wp-content/uploads/2019/02/WP2019-01 final.pdf.

Hurley John, Morris Scott, Portelance Gailyn. 2018. Examining the Debt Implications of the Belt and Road Initiative from a Policy Perspective. W https://www.cgdev.org/ publication/examining-debt-implications-belt-and-roadinitiative-policy-perspective.

Kaczmarski Marcin. 2015. Nowy Jedwabny Szlak: uniwersalne narzędzie chińskiej polityki. W https://www.osw.waw.pl/pl/publikacje/komentarze-osw/2015-02-10/nowyjedwabny-szlak-uniwersalne-narzedzie-chinskiej-polityki.

Kalwasiński Maciej. 2018. „Pas i Szlak” - chińska pułapka kredytowa? W https://www.bankier.pl/wiadomosc/Pas-i-Szlak-chinska-pulapka-kredytowa-Analiza7576219.html.

Kelkar Keshav. 2018. China is building a new Silk Road, and this one is digital. W https://www.orfonline.org/expert-speak/43102-from-silk-threads-to-fiber-optics-therise-of-chinas-digital-silk-road/. 
Kratz Agatha, Feng Allen, Wright Logan. 2019. New Data on the "Debt Trap" Question. W https://rhg.com/research/new-data-on-the-debt-trap-question/.

Lagarde Christine. 2019. BRI 2.0: Stronger Frameworks in the New Phase of Belt and Road. W https://www.imf.org/en/News/Articles/2019/04/25/sp042619-stronger-frameworksin-the-new-phase-of-belt-and-road.

Lu Hui, Rohr Charlene, Hafner Marco, Knack Anna. China Belt and Road Initiative. W https://www.rand.org/content/dam/rand/pubs/research_reports/RR2600/RR2625/RA ND_RR2625.pdf.

Maldives is estimated to have a debt of USD 3 billion to China, Corporate Maledives, https:/corporatemaldives.com/maldives-is-estimated-to-have-a-debt-of-usd-3-billion-tochina/.

Medeiros Evan. 2009. China's International Behavior. Activism, Opportunism, and Diversification. W https://www.rand.org/content/dam/rand/pubs/monographs/2009/ RAND _ MG850.pdf.

Nakano Jane. 2018. China Launches the Polar Silk Road. W https://www.csis.org/ analysis/china-launches-polar-silk-road.

Oleszko-Pyka Bartosz. 2018. Stan wyjątkowy na Malediwach czyli wielka polityka Indii, Chin oraz USA. W http://pulsazji.pl/2018/03/05/stan-wyjatkowy-malediwach-czyliwielka-polityka-indii-chin-oraz-usa/.

Presentation about Asian Infrastructure Investment Bank. W https://www.aiib.org/en/ treasury/_common/_download/IP-Red-August_2019.pdf.

Projects. W https://www.ndb.int/projects/list-of-all-projects/.

Puślecki Zdzisław W. 2019. Unia Europejska - Chiny. Poznań: Wydawnictwo Poznańskie.

Research for TRAN Committee: The new Silk Route - opportunities and challenges for EU transport. W http://www.europarl.europa.eu/RegData/etudes/STUD/2018/585907/ IPOL_STU (2018)585907_EN.pdf.

Resolution of the 19th National Congress of the Communist Party of China on the Revised Constitution of the Communist Party of China. W http:/www.xinhuanet.com/ english/2017-10/24/c_136702726.htm.

Romann Alfred. 2019. Who will benefit from China's Belt and Road Initiative? W https://www.aljazeera.com/news/2019/04/benefit-china-belt-road-initiative190427131051786.html.

Smith Craig. 2019. A Digital Silk Road. W http://www.theworldin.com/article/14433/ edition2018digital-silk-roadhttps://worldin2019.economist.com/Chinaseconomy.

Staff Report for the 2016 Article IV Consultation - Debt Sustainability Analysis. W https://www.imf.org/ /media/Files/Publications/CR/2017/cr1739.ashx.

Tomaszewska Paula, Tomaszewska Sara, Raport: Finansowanie $i$ inwestycje. W https://drive.google.com/file/d/1uWTYVSb7MVjB9TDYObCBWdfXCS1C_wxu/view.

Turkey stays away from China's Belt and Road summit citing debt-trap diplomacy and Uighur concerns. W https://intellinews.com/turkey-stays-away-from-china-s-belt-androad-summit-citing-debt-trap-diplomacy-and-uighur-concerns-160249/.

Vision and Actions on Jointly Building Silk Road Economic Belt and 21st-Century Maritime Silk Road, National Development and Reform Commission. W http://en.ndrc.gov.cn/ newsrelease/201503/t20150330_669367.html. 
Wübbeke Jost, Meissner Mirjam, Zenglein Max, Ives Jaqueline, Conrad Björn. 2016. Made in China 2025. The making of a high-tech superpower and consequences for industrial countries. W https://www.merics.org/sites/default/files/2018-07/MPOC_No.2_Madein China2025_web.pdf.

Xie Tao. 2015. Is China's 'Belt and Road' a Strategy? W https://thediplomat.com/2015/12/ischinas-belt-and-road-a-strategy/.

Yao Kevin. 2018. China Development Bank provides over $\$ 190$ billion for Belt and Road projects. W https://www.reuters.com/article/us-china-finance-cdb-bri/china-develop ment-bank-provides-over-190-billion-for-belt-and-road-projects-idUSKCN1R8095. 